\title{
Evaluation of secondary macronutrients in mango (Mangifera indica L.) Orchard of various districts of Sindh
}

\author{
Mahendar Kumar Sootahar ${ }^{1 *}$, Mehrunisa Memon ${ }^{1}$, Zia-ul- Hassan \\ Shah $^{1}$, Arshad Ali Kaleri ${ }^{2}$, Mukesh Kumar Sootahar ${ }^{1}$, Abdul Khaliq \\ Zounr $^{1}$, Irfan Ali Vistro ${ }^{1}$ and Muhammad Iqbal Jakhro ${ }^{3}$ \\ 1. Department of Soil Science, Sindh Agriculture University, Tandojam-Pakistan \\ 2. Department of Plant Breeding and Genetics, Sindh Agriculture University Tandojam-Pakistan \\ 3. Balochistan Agricultural Research and Development Center Quetta-Pakistan \\ *Corresponding author's email: mahender_935@yahoo.com \\ Mahendar Kumar Sootahar, Mehrunisa Memon, Zia-ul- Hassan Shah, Mukesh Kumar Sootahar, Arshad Ali \\ Kaleri, Abdul Khaliq Zounr, Irfan Ali Vistro and Muhammad Iqbal Jakhro. Evaluation of secondary \\ macronutrients in mango (Mangifera indica L.) Orchard of various districts of Sindh. Pure and Applied Biology. \\ Vol. 6, Issue 4, pp11216-1225. http://dx.doi.org/10.19045/bspab.2017.600129
}

\begin{tabular}{llll}
\hline \hline Received: 06/05/2017 & Revised: 22/08/2017 & Accepted: 15/09/2017 & Online First: 21/09/2017 \\
\hline \hline
\end{tabular}

\section{Abstract}

This study was carried out to evaluate the soil and leaf tissue status of mango orchards of Matiari, Hyderabad, Tando Allahyar and Mirpurkhas districts of Sindh. In this regard, soil samples were analyzed for some physic-chemical properties (texture, $\mathrm{EC}_{\mathrm{e}}, \mathrm{pH}_{1: 5}$, calcium carbonate, organic matter, ammonium acetate extractable $\mathrm{Ca}, \mathrm{Mg}$ and calcium chloride extractable S) at two soil depths (0-15 and 15-30 cm). The mango orchard soils of Hyderabad, Tando Allahyar and Mirpurkhas were silty clay loams except Matiari soils which were clay loams. The average $\mathrm{pH}$ values at surface and sub-surface soils falling in medium category. Organic matter content of $0-15 \mathrm{~cm}$ soil was higher $(1.32,1.32,1.15$ and $1.25 \%)$ compared to $15-30 \mathrm{~cm}$ soil $(0.87,0.79,0.86$ and $0.86 \%)$ respectively. Calcium carbonate contents of the study area varied from slightly calcareous $(0-13 \%)$ to moderately calcareous $(13-26 \%)$. The ammonium acetate extractable $\mathrm{Ca}, \mathrm{Mg}$ and calcium chloride extractable S contents were 3016, 2971; 1127, 1228; and 42, $47 \mathrm{mg} \mathrm{kg}^{-1}$ in Matiari, 2921, 2721; 1215, 1389 and 45, $66 \mathrm{mg} \mathrm{kg}^{-1}$ in Hyderabad, 2740, 2583; 1424, 1478 and 207, $263 \mathrm{mg} \mathrm{kg}^{-1}$ in Tando Allahyar and 2866, 2882; 1244, 1222 and 285, $482 \mathrm{mg} \mathrm{kg}^{-1}$ in Mirpurkhas at 0-15 and 15-30 cm soil depth respectively. Total $\mathrm{Ca}, \mathrm{Mg}$ and $\mathrm{S}$ contents in mango leaf tissue were $2.51,0.64$ and $0.54 \%$ in Matiari, 2.48, 0.69 and $0.37 \%$ in Hyderabad, 2.51, 0.67 and $0.62 \%$ in Tando Allahyar and 2.51, 0.61 and $0.60 \%$ in Mirpurkhas respectively. It can be concluded from this study that the Ca and $\mathrm{Mg}$ contents in soil were adequate and sufficient, and high in leaf tissues respectively. Generally there was no problem regarding S contents in soil and leaf tissues, however, 33\% leaf tissue samples were low in each Tando Allahyar and Mirpurkhas.

Keywords: Macronutrients; Physio-chemical properties; Mango

Introduction

Pakistani mangoes are considered as a best and fetch a good price in international market due to their taste and flavor. Currently mango (Mangifera indica L.) is grown in more than 80 countries. Pakistan stands fourth largest mango producer and exporter in the world [1]. Sindh is a major mango growing province producing most of the varieties in district Matiari, Hyderabad, Tando Allahyar, Mirpurkhas, including Sukkhar, Karachi and some other districts 
$[2,3]$. Approximately, $62 \%$ of total mango production comes from Sindh province. Crop yield efficiency depends on the available nutrient status of soil [4]. Therefore an optimum supply and nutrients uptake shows a good response in growth of the plant and nutrient export. Sindh province is blessed with good climatic conditions, which not only can increase the production but improve the fruit quality to get better position in international market. Nutrients play vital role in the plants' growth, development, production and quality of fruit and mango is no exception to this. The major nutrients required by mango tree include macronutrients like nitrogen $(\mathrm{N})$, phosphorus $(\mathrm{P})$, potassium $(\mathrm{K})$, calcium $(\mathrm{Ca})$, magnesium $(\mathrm{Mg})$ and sulphur (S). These nutrients are required for different tree functions at different times. Nitrogen is required for mango tree vigor, vegetative and floral growth [5], $\mathrm{P}$ for cell division, growth and formation of sugarphosphate molecules, $\mathrm{K}$ for resistance against pathogens and insect pests, regulating water uptake [6] and fruit quality [7]. Whereas $\mathrm{Ca}$ provides membrane stability and strengthens cell walls, $\mathrm{Mg}$ is main part of chlorophyll and $\mathrm{S}$ is part of enzymes and proteins [8]. The optimum supply of these macronutrients at right time forms the basis for mango production on sustainable basis and ensures the fruit quality [9]. The secondary macronutrients i.e. $\mathrm{Ca}, \mathrm{Mg}$ and $\mathrm{S}$ play a significant role in the production and quality of mango. $\mathrm{Ca}$ is greatly required in new flushes right after the harvesting of mango and in maintaining the fruit firmness which may disturb the $\mathrm{Ca}$ : $\mathrm{N}$ ratio in soil and leaf [10]. Calcium is considered as a secondary plant nutrient. Magnesium is the constituent of chlorophyll molecule. It is very important for the formation of seeds rich in oil. It supports in translocation of starches and regulates other nutrients uptake. Sulphur is the main and basic component of amino acids (cysteine and methionine) and therefore is indispensable part for synthesis (photosynthetic) of proteins, the vitamins (thiamine and biotin) and coenzyme-A which are used in the breakdown and synthesis of fatty acids [11].

\section{Materials and methods}

The present study entitled "evaluation of secondary macronutrient $(\mathrm{Ca}, \mathrm{Mg}$ and $\mathrm{S}$ ) in mango orchards of lower Sindh" comprised of four mango growing districts i.e. Matiari, Hyderabad, Tando Allahyar and Mirpurkhas. The details relating to soil and plant sample collection, processing and analytical methods applied are discussed in this chapter.

\section{Soil collection, processing and analysis}

District Tando Allahyar was selected for mango sampling. Three mango trees of same age and appearance were randomly selected from an orchard and tagged for soil and leaf sampling. Soil samples were collected at 0-15 and $15-30 \mathrm{~cm}$ depth. In order to have a representative soil sample from each tree four cores were dug around the tree canopy and composited depth-wise. Soil samples were preserved in labeled polythene bags and brought to the soil Fertility Research Laboratory, Department of Soil Science, Sindh Agriculture University, Tandojam.

\section{Leaf tissue collection, processing and analysis}

Leaf samples were collected from the same tagged trees of same district during the growth period when the nutrients were most stable (i.e. about two weeks after the emergence of flower panicles) [12]. About 25 recently matured leaves ( $3^{\text {rd }}$ leaf from top) of fruit bearing branches were collected around each tree and composited to one sample [13]. The samples were placed in a paper envelop, labeled and delivered to laboratory within 10 hours. Leaf samples were cleaned with tap water and then with distilled water using the method as described by [14]), oven-dried at $68^{\circ} \mathrm{C}$ for 48 hours, ground to $20 \mathrm{~mm}$ mesh in stainless agate mill and stored. The ground mango leaf samples were subjected to total $\mathrm{Ca}$ and $\mathrm{Mg}$ analysis. The leaf samples were first wet digested using nitric acid-perchloric acid 
$\left(\mathrm{HNO}_{3} \mathrm{HClO}_{4}\right)$ mixture (2:1). The digests were analyzed for $\mathrm{Ca}$ and $\mathrm{Mg}$ by EDTA titration method [15]. Total S in mango leaves was determined by first digesting the leaf tissue material in an acid mixture, followed by $\mathrm{S}$ analysis on spectrophotometer by turbidimetric method [16].

\section{Statistical analysis and interpretation}

The $\mathrm{Ca}, \mathrm{Mg}$ and $\mathrm{S}$ contents of mango orchards belonging to Matiari, Hyderabad, Tando Allahyar, and Mirpurkhas were subject to descriptive statistics using software Statistix 8.0. The mean leaf tissue nutrients were evaluated by comparing the analytical data with established critical levels of mango as given by [17]. Soil $\mathrm{Ca}$ and $\mathrm{Mg}$ and $\mathrm{S}$ in mango orchards were considered low to high according to the categorization as given by [18 and 19].

\section{Results}

Particle size distribution (\%)

The particle size analysis of various mango soils in Matiari, Hyderabad, Tando Allahyar and Mirpurkhas at two soil depths $(0-15$ and $15-30 \mathrm{~cm})$ are presented in Figure 1. The data regarding particle size distribution showed a sand, silt and clay percent of 20.2, 47.3 and 32.5 and 22.7, 47.3 and 30.0 in Matiari, 12.7, 55.0, and 32.3 and 15.2, 52.5 and 32.3 in Hyderabad, 15.2, 42.5 and 42.3 and 15.2, 25.0, 59.8 in Tando Allahyar and 7.7, 64.8 and 27.5 and 17.7, 52.3 and 30.0 in Mirpurkhas districts at surface and sub surface soils respectively. According to these values, all the soils were classified to have a silty clay loam texture at both $0-15$ and $15-30 \mathrm{~cm}$ except the soils of Matiari district, which possessed a clay loam texture at both depths.

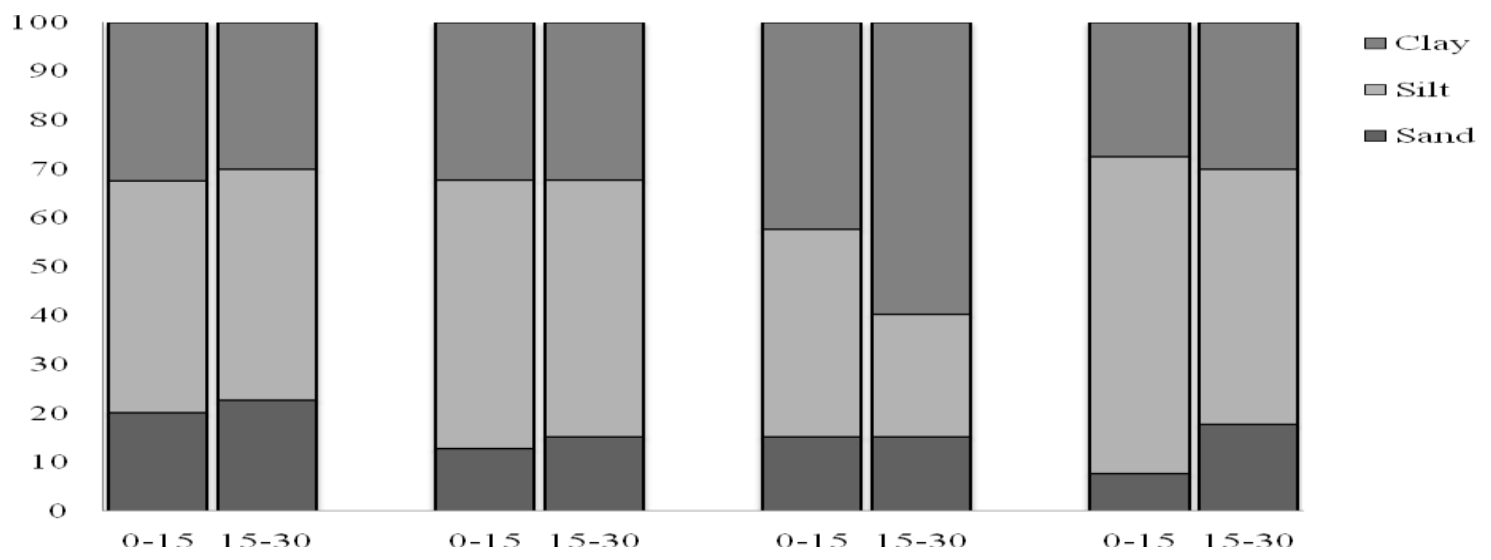

Low (<800) Marginal (800-2000) Adequate (>2000), Source: London (1984) and NFDC (1994) Figure 1. The particle size analysis of various mango soils in Matiari, Hyderabad, Tando Allahyar and Mirpurkhas at two soil depths $(0-15$ and $15-30 \mathrm{~cm})$

\section{Electrical conductivity $\left(\mathbf{d S ~ m}^{-1}\right)$}

The data regarding electrical conductivity of mango soils in four districts of Sindh at two soil depths $(0-15$ and $15-30 \mathrm{~cm})$ is presented in Figure 2. The soils of all mango orchards were non-saline showing EC values less than $2 \mathrm{dS} \mathrm{m^{-1 }}$ according to the soil salinity categorization as given by [20]. The lowest electrical conductivity values of 0.22 and $0.21 \mathrm{dS} \mathrm{m}^{-1}$ were observed in district Matiari and highest of
0.87 and $1.24 \mathrm{dS} \mathrm{m}^{-1}$ in district Mirpurkhas at $0-15$ and $15-30 \mathrm{~cm}$ soil depth respectively. The electrical conductivity values of surface soils ranged between 0.22 and $0.27 \mathrm{dS} \mathrm{m}^{-1}$ in Matiari, 0.25 and 0.27 $\mathrm{dS} \mathrm{m}^{-1}$ in Hyderabad, 0.56 and $0.66 \mathrm{dS} \mathrm{m}^{-1}$ in Tando Allahyar and 0.77 and $0.81 \mathrm{dS} \mathrm{m}^{-}$ 1 in Mirpurkhas districts. The respective average values for surface soils were 0.24 $\mathrm{dS} \mathrm{m}^{-1}$ in Matiari, $0.26 \mathrm{dS} \mathrm{m}^{-1}$ in Hyderabad, $0.60 \mathrm{dS} \mathrm{m}^{-1}$ in Tando Allahyar 
and $0.80 \mathrm{dS} \mathrm{m}^{-1}$ in Mirpurkhas. The electrical conductivity values of subsurface soils ranged between 0.21 and 0.25 $\mathrm{dS} \mathrm{m} \mathrm{m}^{-1}$ in Matiari, 0.25 and $0.59 \mathrm{dS} \mathrm{m}^{-1}$ in Hyderabad, 0.59 and $0.64 \mathrm{dS} \mathrm{m}^{-1}$ in Tando Allahyar and 0.82 and $1.24 \mathrm{dS} \mathrm{m}^{-1}$ in
Mirpurkhas district. The respective average values in sub-surface soils were between $0.23 \mathrm{dS} \mathrm{m}^{-1}$ in Matiari, $0.27 \mathrm{dS} \mathrm{m}^{-1}$ in Hyderabad, $0.62 \mathrm{dS} \mathrm{m}^{-1}$ in Tando Allahyar and $1.00 \mathrm{dS} \mathrm{m}^{-1}$ in Mirpurkhas.

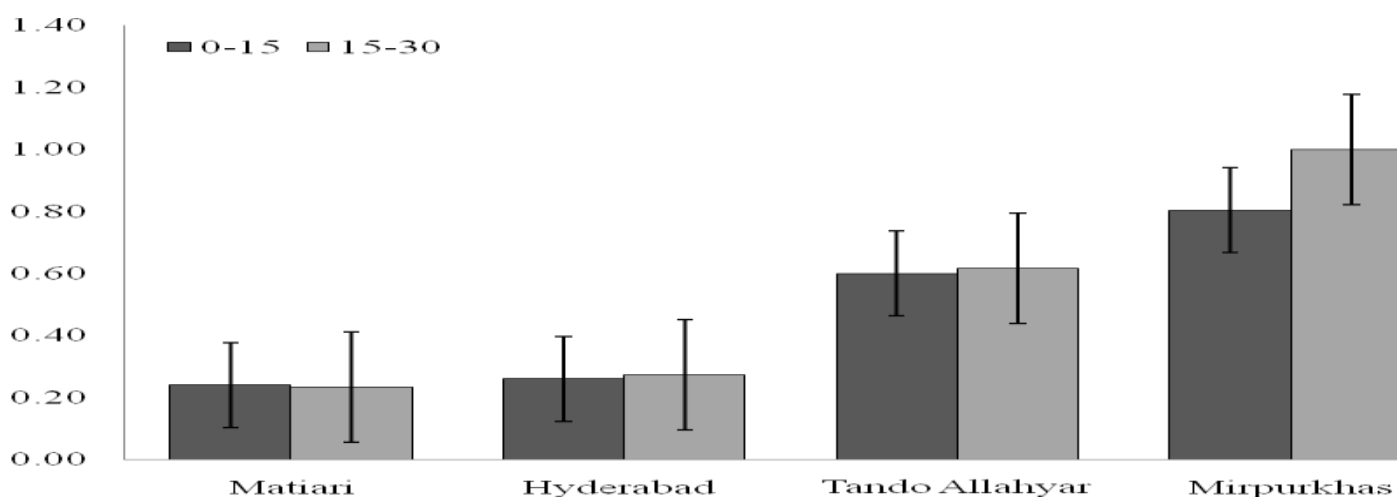

Figure 2. Electrical conductivity $\left(\mathrm{dS} \mathrm{m}^{-1}\right)$ of mango orchard soils in Sindh

pH

The soil $\mathrm{pH}$ of mango orchards in Matiari, Hyderabad, Tando Allahyar and Mirpurkhas of Sindh is given in Figure 3. The $\mathrm{pH}$ of surface soils ranged between 7.30 and 7.40 in Matiari, 7.72 and 7.80 in Hyderabad, 7.30 and 7.74 in Tando Allahyar and 7.45 and 7.80 in Mirpurkhas. The average $\mathrm{pH}$ values were 7.33 in Matiari, 7.77 in Hyderabad, 7.58 in Tando Allahyar and 7.68 in Mirpurkhas. The subsurface soil $\mathrm{pH}$ ranged between 7.40 and
7.77 in Matiari, 7.75 and 7.79 in Hyderabad, 7.67 and 7.80 in the Tando Allahyar and 7.80 and 7.88 in Mirpurkhas The respective average $\mathrm{pH}$ values for subsurface soils were 7.53 in Matiari, 7.77 in Hyderabad, 7.72 in Tando Allahyar and 7.82 in Mirpurkhas. All surface and subsurface soils of four districts were categorized as medium, falling between a $\mathrm{pH}$ range of 7.60-8.00 as reported by [21].

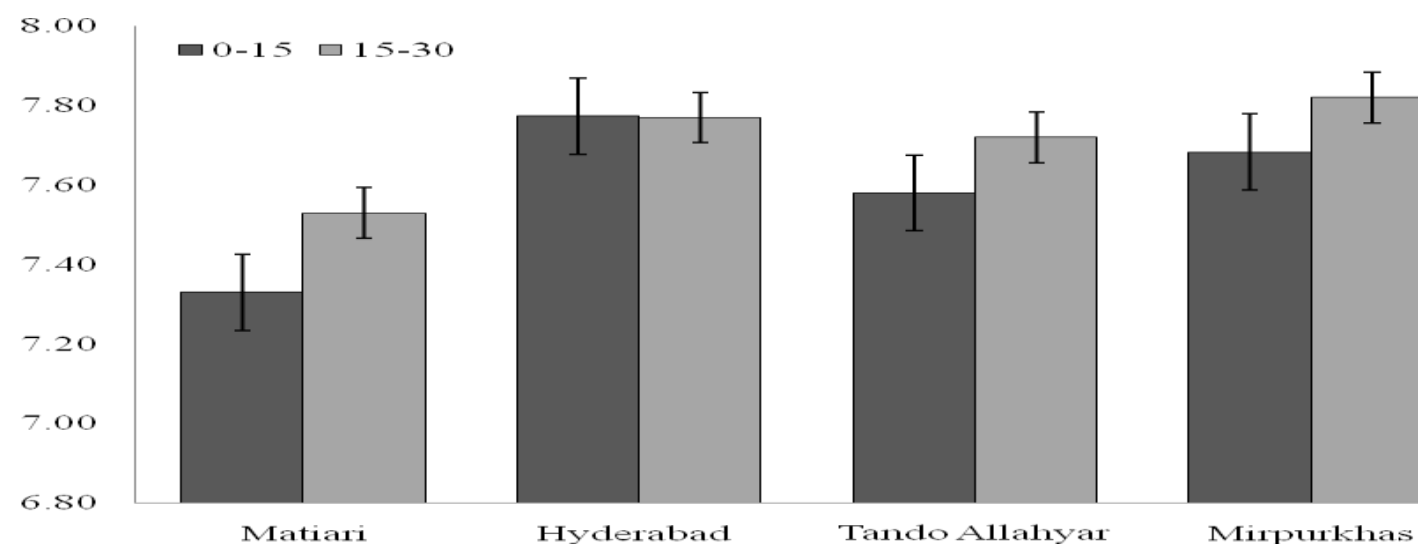

Figure 3. The soil pH of mango orchards in Matiari, Hyderabad, Tando Allahyar and Mirpurkhas of Sindh

\section{Organic matter (\%)}

The analytical results regarding organic matter contents as presented in Figure 4 showed that the organic matter content was high at surface as compared to the sub- surface soil horizons of all mango orchards. The minimum and maximum organic matter contents at $0-15 \mathrm{~cm}$ soil depth were 1.29 and $1.35 \%$ in Matiari, 1.04 and $1.48 \%$ in Hyderabad, 0.80 and $1.39 \%$ in Tando 
Allahyar and 0.94 and $1.52 \%$ in Mirpurkhas. The average organic matter contents at surface were $1.32 \%$ in Matiari, $1.32 \%$ in Hyderabad, $1.15 \%$ in Tando Allahyar and $1.25 \%$ in Mirpurkhas. In case of sub-surface soils, minimum and maximum organic matter contents were between 0.66 and $1.02 \%$ in Matiari, 0.32 and $1.14 \%$ in Hyderabad, 0.43 and $1.32 \%$ in Tando Allahyar and 0.40 and $1.36 \%$ in Mirpurkhas. The respective average organic matter contents were $0.87 \%$ in
Matiari, $0.79 \%$ in Hyderabad, $0.86 \%$ in Tando Allahyar and $0.86 \%$ in Mirpurkhas According to the soil organic matter categorization as given by [17], the soil organic matter contents of surface soils were either in the range of 0.86-1.29\% categorized as medium (Tando Allahyar and Mirpurkhas) or high being $>1.29 \%$ (Matiari and Hyderabad). All sub-surface soils also had organic matter contents between 0.86 and $1.29 \%$, categorized as medium.
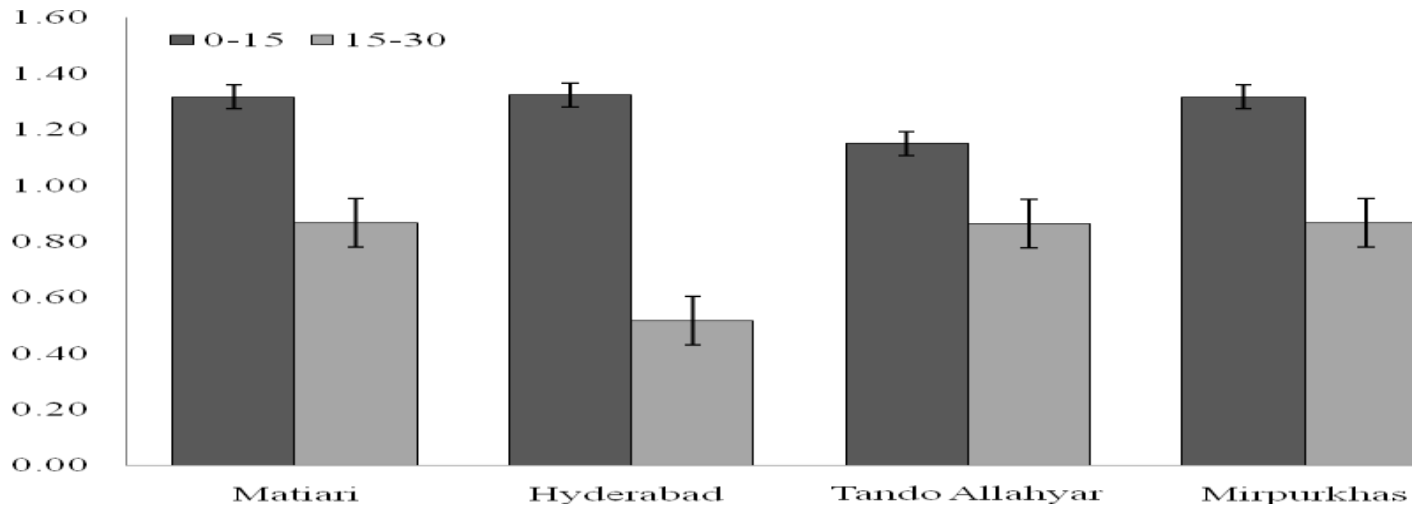

Figure 4. Organic matter (\%) of mango orchard soils in Sindh

\section{Calcium carbonate $(\%)$}

The data regarding calcium carbonate contents of mango orchard soils in Sindh at $0-15$ and $15-30 \mathrm{~cm}$ depth is presented in Figure 5. The calcium carbonate contents ranged between 11.0 and $15.0 \%$ and 4.5 and $9.5 \%$ in Matiari, 11.0 and $13.0 \%$ and 10.0 and $13.1 \%$ in Hyderabad, 8.5 and $11.0 \%$ and 3.5 and $13.0 \%$ in Tando Allahyar and 4.5 and 7.0 $\%$ and 3.5 and $10.5 \%$ in Mirpurkhas respectively at $0-15$ and $15-30 \mathrm{~cm}$ soil depth. The average values at $0-15$ and 15-
$30 \mathrm{~cm}$ soil depth were 12.8 and $7.5 \%$, in Matiari, 12.1 and $12.1 \%$ in Hyderabad, 9.3 and $7.8 \%$ in Tando Allahyar and 6.0 and 7.0 in Mirpurkhas. The comparison of calcium carbonate contents of the study area with the calcium carbonate contents as given by Jackson (1969) categorization for calcareous soils, revealed that all the mango orchard soils belonging to four districts fall in slightly calcareous category (0-13\%) except those of Hyderabad which were moderately calcareous (13-26\%).

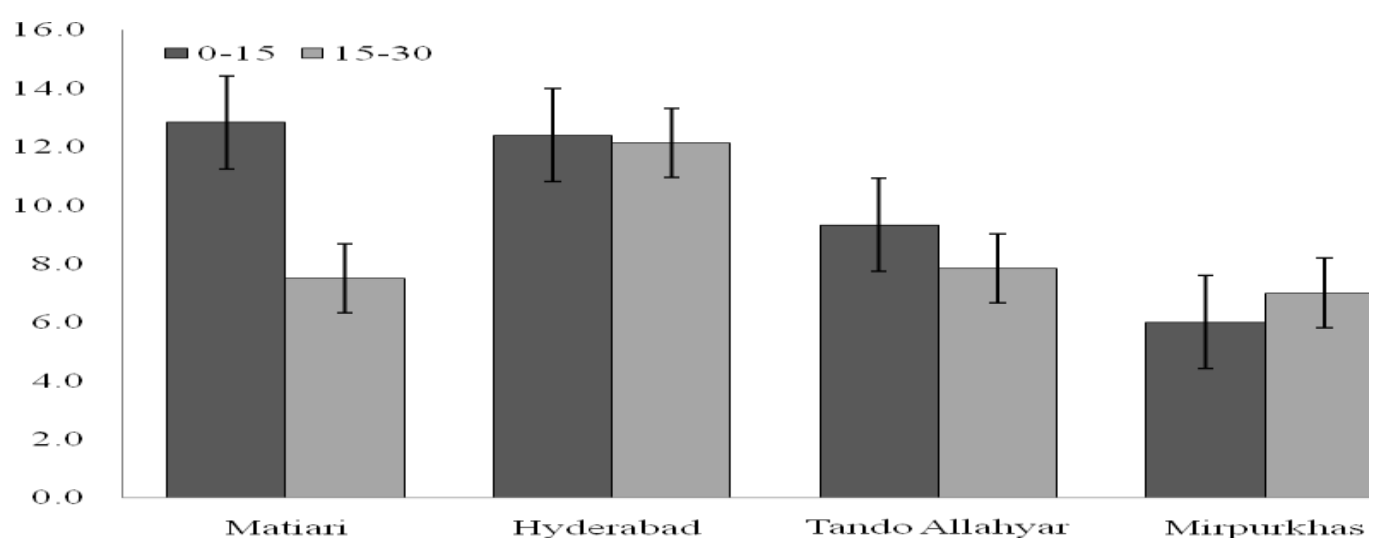


Figure 5. Calcium carbonate (\%) of mango orchard soils in Sindh

Ammonium acetate extractable $\mathrm{Ca}$ in soil $\left(\mathrm{mg} \mathrm{kg}^{-1}\right)$

The data regarding ammonium acetate extractable $\mathrm{Ca}$ in mango orchard surface soils $(0-15 \mathrm{~cm})$ as illustrated in Figure 6 gave minimum and maximum contents of 2760 and $3214 \mathrm{mg} \mathrm{kg}^{-1}$ in Matiari, 2640 and $3412 \mathrm{mg} \mathrm{kg}^{-1}$ in Hyderabad, 2662 and 2812 $\mathrm{mg} \mathrm{kg}^{-1}$ in Tando Allahyar and 2402 and $2674 \mathrm{mg} \mathrm{kg}^{-1}$ in Mirpurkhas. The average values were $3016 \mathrm{mg} \mathrm{kg}^{-1}$ in Matiari, 2932 $\mathrm{mg} \mathrm{kg}{ }^{-1}$ in Hyderabad, $2740 \mathrm{mg} \mathrm{kg}^{-1}$ in Tando Allahyar and $2866 \mathrm{mg} \mathrm{kg}$ in Mirpurkhas. The $\mathrm{Ca}$ contents at $15-30 \mathrm{~cm}$ soil depth were 2498 and $3452 \mathrm{mg} \mathrm{kg}^{-1}$ in Matiari, 2306 and $3114 \mathrm{mg} \mathrm{kg}^{-1}$ in Hyderabad, 2402 and $2674 \mathrm{mg} \mathrm{kg}^{-1}$ in Tando Allahyar and 2810 and $2924 \mathrm{mg} \mathrm{kg}^{-}$ 1 in Mirpurkhas with average values of 2971, 2721, 2583 and $2882 \mathrm{mg} \mathrm{kg}^{-1}$ in Matiari, Hyderabad, Tando Allahyar and Mirpurkhas respectively.

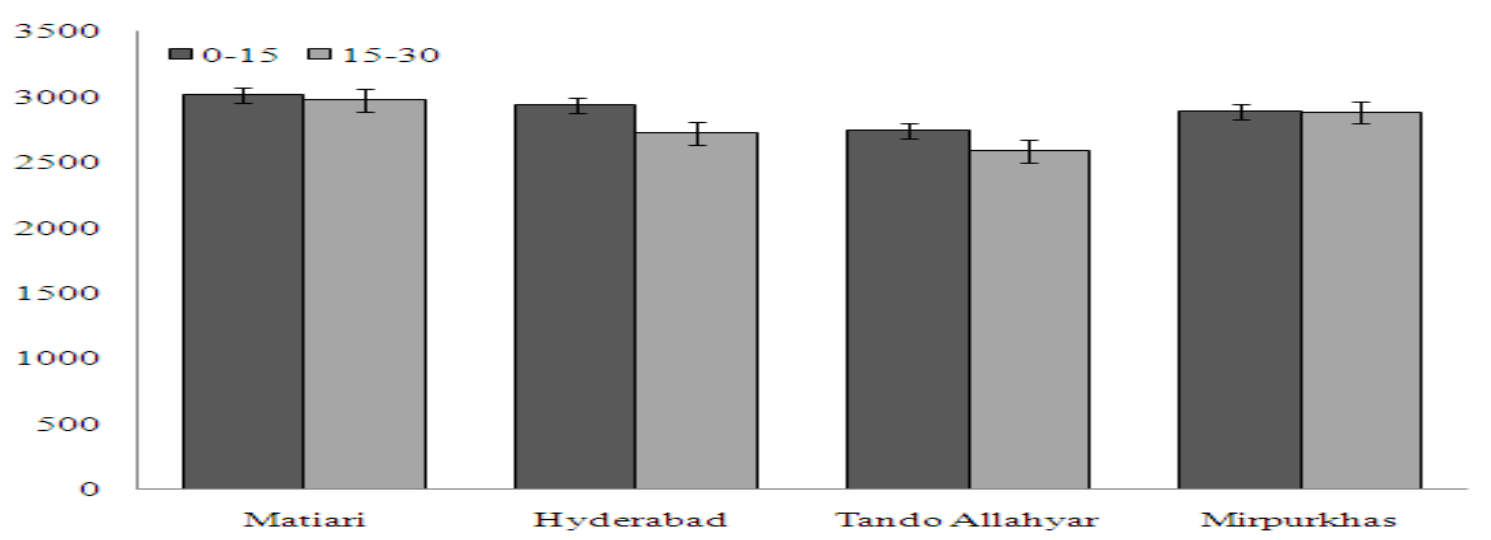

Figre 6. Ammonium acetate extractable Ca $\left(\mathrm{mg} \mathrm{kg}^{-1}\right)$ of mango orchard soils in Sindh

Ammonium acetate extractable $\mathrm{Mg}(\mathrm{mg}$ $\mathrm{kg}^{-1}$ soil)

Extractable $\mathrm{Mg}$ in soils of various districts at two depts. (0-15 and $15-30 \mathrm{~cm})$ is presented in Figure 7. The minimum and maximum $\mathrm{Mg}$ contents at $0-15 \mathrm{~cm}$ soil depth were 1022 and $1236 \mathrm{mg} \mathrm{kg}^{-1}$ in Matiari, 1030 and $1315 \mathrm{mg} \mathrm{kg}^{-1}$ in Hyderabad, 1346 and $1508 \mathrm{mg} \mathrm{kg}^{-1}$ in Tando Allahyar and 1212 and $1264 \mathrm{mg} \mathrm{kg}^{-}$ ${ }^{1}$ in Mirpurkhas. The average values were $1127 \mathrm{mg} \mathrm{kg}^{-1}$ in Matiari, $1215 \mathrm{mg} \mathrm{kg}^{-1}$ in
Hyderabad, $1224 \mathrm{mg} \mathrm{kg}^{-1}$ in Tando Allahyar and $1244 \mathrm{mg} \mathrm{kg}^{-1}$ in Mirpurkhas. The Mg contents in soil at $15-30 \mathrm{~cm}$ soil depth were between 940 and $1514 \mathrm{mg} \mathrm{kg}^{-1}$ in Matiari, 1216 and $1583 \mathrm{mg} \mathrm{kg}^{-1}$ in Hyderabad, 1470 and $1489 \mathrm{mg} \mathrm{kg}^{-1}$ in Tando Allahyar and 1494 and $1274 \mathrm{mg} \mathrm{kg}^{-}$

1 in Mirpurkhas with average $\mathrm{Mg}$ contents of $1228,1389,1378$ and $1222 \mathrm{mg} \mathrm{kg}^{-1}$ in Matiari, Hyderabad, Tando Allahyar and Mirpurkhas respectively.

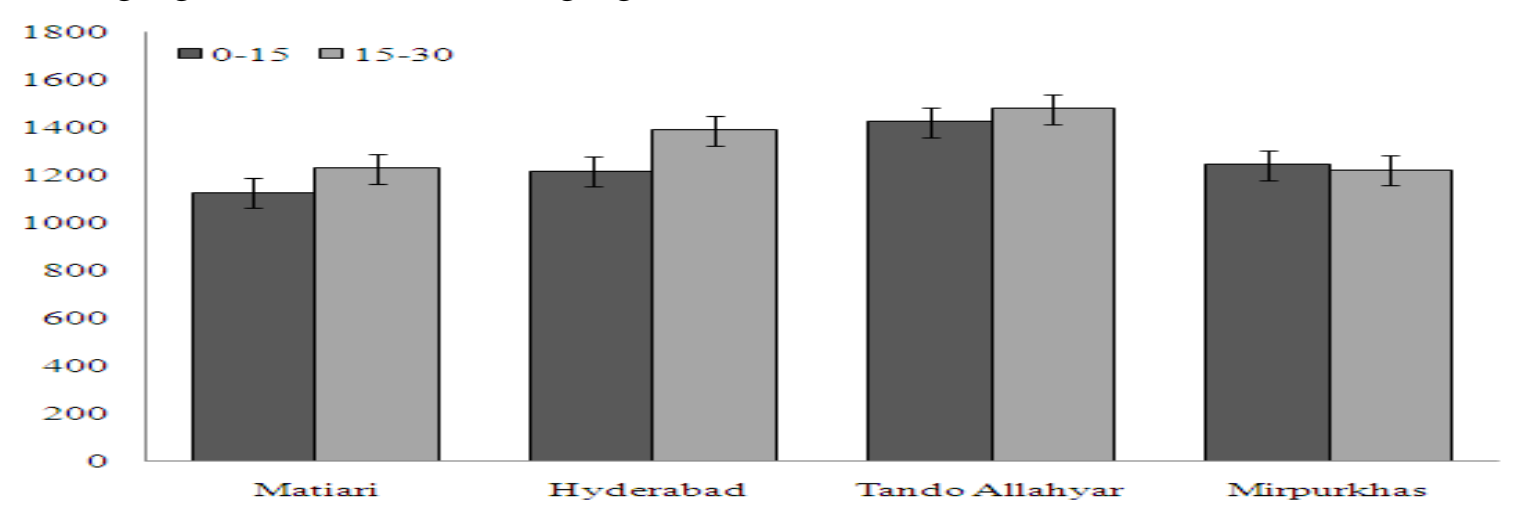

Figure 7. Extractable $\mathrm{Mg}$ in soils of various districts at two depts. $(0-15$ and $15-30 \mathrm{~cm})$ 
Calcium chloride extractable $\mathbf{S}\left(\mathrm{mg} \mathrm{kg}^{-1}\right)$

The data regarding extractable $\mathrm{S}$ as presented in Figure 8 showed highest content in Mirpurkhas (285 and $482 \mathrm{mg} \mathrm{kg}^{-}$ ${ }^{1}$ soil), followed by Tando Allahyar (207 and $263 \mathrm{mg} \mathrm{kg}^{-1}$ soil), Hyderabad (45 and $66 \mathrm{mg} \mathrm{kg}^{-1}$ soil) and Matiari (42 and $47 \mathrm{mg}$ $\mathrm{kg}^{-1}$ soil) respectively at $0-15$ and $15-30 \mathrm{~cm}$. Extractable $\mathrm{S}$ content ranged between 26 and $51 \mathrm{mg} \mathrm{kg}^{-1}$ soil in Matiari, 38 and 53 mg kg${ }^{-1}$ soil in Hyderabad, 205 and $257 \mathrm{mg}$ $\mathrm{kg}^{-1}$ soil in Tando Allahyar and 204 and 359 $\mathrm{mg} \mathrm{kg}^{-1}$ soil in Mirpurkhas in surface soils. The sub-surface soils showed a smaller reduction in values ranging between 28 and $65 \mathrm{mg} \mathrm{kg}^{-1}$ soil in Matiari, 42 and $80 \mathrm{mg} \mathrm{kg}^{-}$ ${ }^{1}$ soil in Hyderabad, 243 and $283 \mathrm{mg} \mathrm{kg}^{-1}$ soil in Tando Allahyar and 390 and $539 \mathrm{mg}$ $\mathrm{kg}^{-1}$ soil in Mirpurkhas.

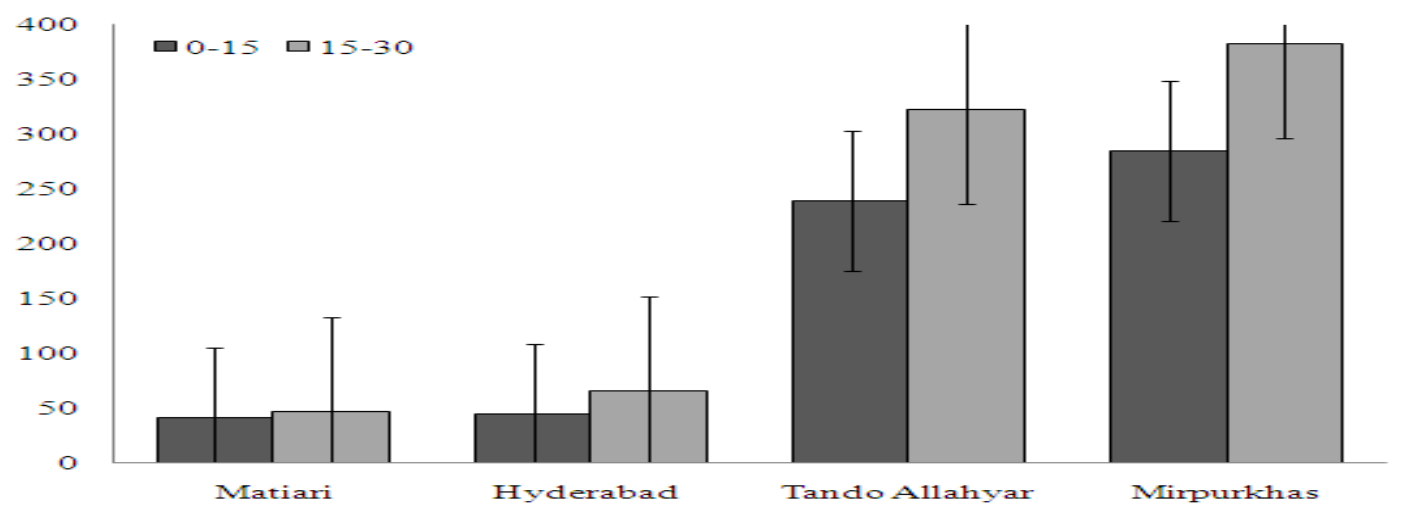

Figure 8. Calcium chloride extractable $S\left(\mathrm{mg} \mathrm{kg}^{-1}\right.$ soil) of mango orchards in Sindh

Leaf tissue contents (\%)

Leaf tissue of mango orchards in various districts was tested for total nutrient contents. The results related to total $\mathrm{Ca}$, $\mathrm{Mg}$ and $\mathrm{S}$ contents being presented in Figures 9-11. The leaf tissue Ca contents of mango orchards belonging to district Matiari, Hyderabad, Tando Allahyar and Mirpurkhas are presented in Figure 9. The concentrations varied to a small extent among all four districts. The average values were $2.48 \%$ in Hyderabad, followed by $2.51 \%$ in Mirpurkhas, Tando Allahyar and Matiari having almost similar $\mathrm{Ca}$ contents. The values ranged between 2.48 and $2.56 \%$ in Matiari, 2.32 and $2.80 \%$ in Hyderabad, 2.32 and 2.72 $\%$ in Tando Allahyar and 2.40 and $2.64 \%$ in Mirpurkhas.

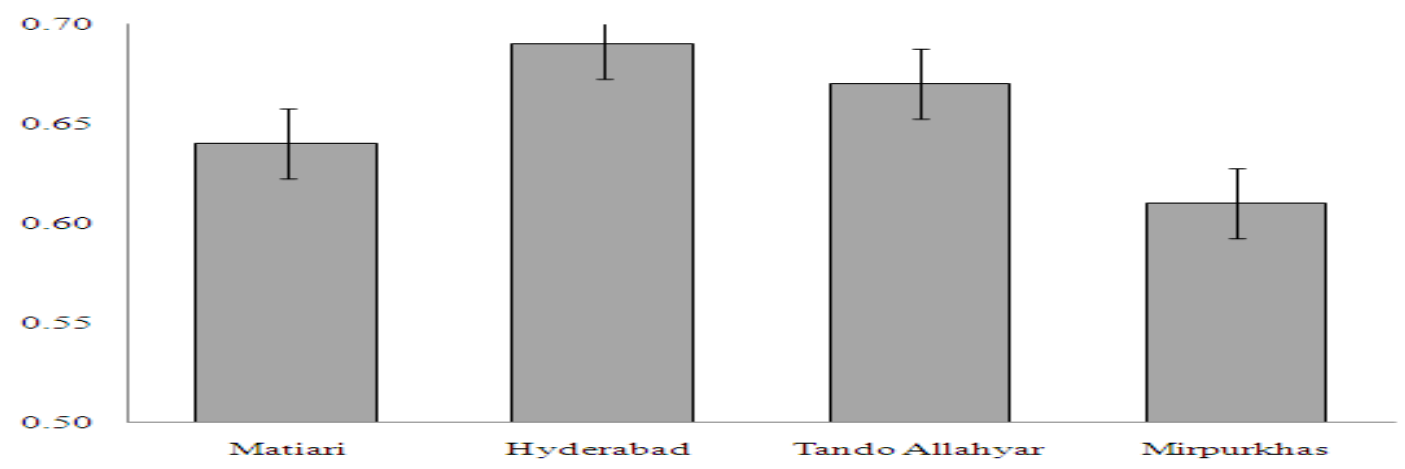

Figure 9. Leaf tissue Ca (\%) in mango orchards of Sindh

\section{Leaf tissue Mg contents}

The leaf tissue $\mathrm{Mg}$ contents in various orchard of Sindh are presented in Figure 10. Average Mg contents were 0.64, 0.69, 0.67 and $0.61 \%$ respectively in mango orchards of Matiari, Hyderabad, Tando Allahyar and Mirpurkhas respectively with minor variation among districts. The values 
ranged between 0.53 and $0.72 \%$ in Matiari, 0.67 and $0.72 \%$ in Hyderabad, 0.62 and $0.72 \%$ in Tando Allahyar and 0.58 and 0.67 $\%$ in Mirpurkhas. Total S in leaf tissue of mango orchards as presented in Figure 11 showed lowest $\mathrm{S}$ contents of $0.37 \%$ in Hyderabad, followed by $0.54 \%$ in Matiari, $0.60 \%$ in Mirpurkhas and $0.62 \%$ in Tando
Allahyar having wide variability in $S$ content among districts. However, the contents were more or less similar in Hyderabad and Tando Allahyar. Sulphur leaf tissue contents varied from as low as 0.46 to $0.67 \%$ in Matiari, 0.34 to $0.40 \%$ in Hyderabad, 0.48 to $0.72 \%$ in Tando Allahyar and 0.20 to $0.82 \%$ in Mirpurkhas.

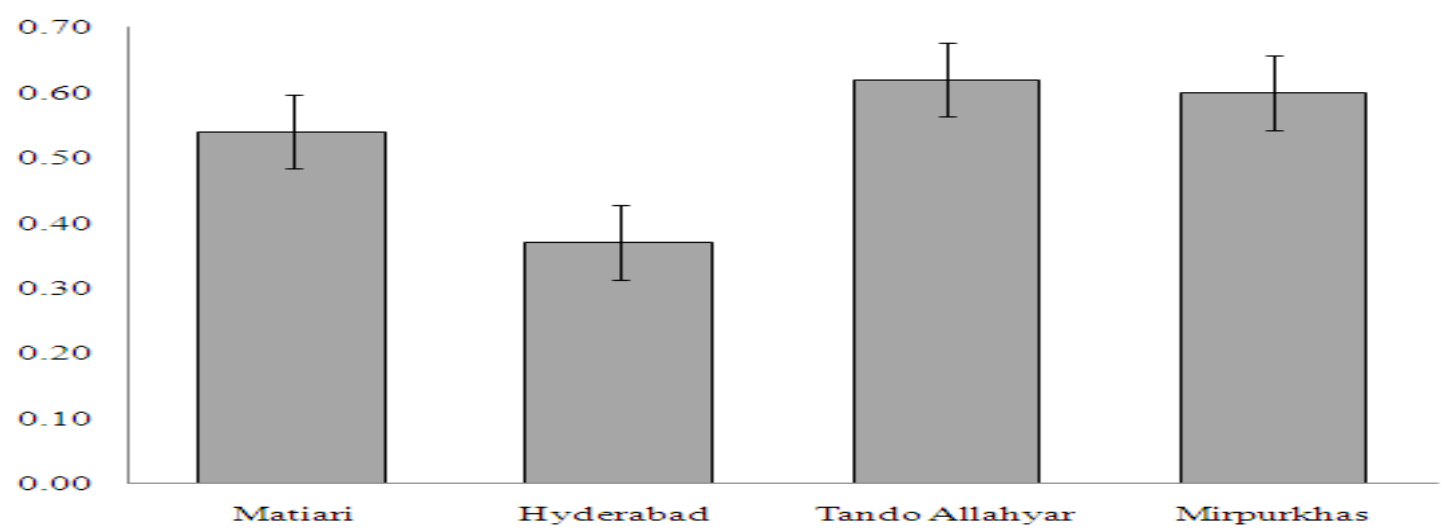

Figure 10. Leaf tissue Mg (\%) in mango orchards of Sindh

\section{Discussion}

The secondary macronutrients $\mathrm{Ca}, \mathrm{Mg}$ and $\mathrm{S}$ are equally important as the primary nutrients N, P and K. Calcareous soils have high amounts of calcium carbonate and at $\mathrm{pH} 7.8$ or more, and calcium and magnesium are abundant. Due to their abundance in our environment, they are never considered deficient or evaluated to be considered low or sufficient, especially with regard to $\mathrm{Ca}$ and $\mathrm{Mg}$. Apart from presence of $\mathrm{S}$ minerals, $\mathrm{S}$ is mostly part of many fertilizers such as single super phosphate, ammonium sulphate and potassium sulphate [22]. This is why majority of the studies conducted on mango nutrition do not include the assessment of $\mathrm{Ca}, \mathrm{Mg}$ and $\mathrm{S}$ in soil and plant. These three nutrients i.e. $\mathrm{Ca}, \mathrm{Mg}$ and $\mathrm{S}$ play a significant role in the production and quality of mango. Calcium is greatly required in new flushes right after the harvesting of mango and maintaining the fruit firmness which may disturb the $\mathrm{Ca}$ : $\mathrm{N}$ ratio in soil and leaf [10]. These results regarding $\mathrm{Ca}$ contents in soil were in line with the results obtained by [23] on Kalan mangoes of Egypt. The result obtained by them showed mean $\mathrm{Ca}$ contents of 2.65 meq $\mathrm{L}^{-1}$. Magnesium is part of chlorophyll molecule and enzymes and helps in P transport [24]. Magnesium is the constituent of chlorophyll molecule and plays an important role in facilitating the translocation of phosphorous [25]. The Mg contents in soil of four districts of Sindh were adequate and varied in leaf tissues. The results were in line with the results obtained by [23]. Sulphur, being part of volatile compounds is responsible for pungent smell or characteristic odour in many plants such as onion, mustard, garlic, etc. performing the role of an enzymatic activator [6]. The extractable $\mathrm{S}$ contents were in soil $67 \%$ was adequate and $33 \%$ was low. The leaf tissue $\mathrm{S}$ content was lowest $(0.37 \%)$ in Hyderabad and highest $(0.62 \%)$ in Tando Allahyar.

\section{Conclusion}

The $\mathrm{Ca}$ and $\mathrm{Mg}$ contents in soil were adequate and sufficient, and high in leaf tissue respectively. Generally there was no problem regarding $\mathrm{S}$ contents in soil 
and leaf tissue, however, 33\% leaf tissue samples were low in each Tando Allahyar and Mirpurkhas. The other two districts had adequate $S$ but were at the edge of satisfactory range which was further proved from the low status of leaf $S$ contents. Through this study along with review of literature, it can be inferred that $\mathrm{S}$ stocks are being reduced with time, and unless replenished may affect the quality of mango. It is suggested that a three year consecutive sampling at various growth stages of mango will help to understand the fluctuation of these nutrients.

\section{Authors' Contributions}

Conceived and designed the experiments: MUN Memon \& MK Sootahar, Performed the experiments: MK Sootahar, MK Sootahar, AK Zounr, I Vistro \& MI Jakhro, Analyzed the data: ZUH Shah \& MK Sootahar, Wrote the paper: AA Kaleri \& MK Sootahar.

\section{Refrences}

1. Pakistan Horticulture Development \& Export Company PHDEC (2012), Ministry of Commerce, Govt. of Pakistan.

2. Jilani, MS., Bibi F, Waseem K \& Khan MA (2006). Evaluation of physicochemical characteristics of mango (Mangifera Indica L.) cultivars grown in D. I. Khan. J Agri Res, 48(2): 201207.

3. Rajwana, IA., Khan IA, Malik AU, Saleem BA, Khan AS, Zaif K, Anwar R \& Amin M (2011). Morphological and biochemical markers for varietal characterization and quality assessment of potential indigenous mango (Mandifera indica) germplasm. Int J Agric Biol, 13(2): 151-15.

4. Khan, A, Jan MT, Marwat KB \& Arif.M (2009). Organic and inorganic nitrogen management effects on plant and yield attributes of maize in a different tillage system. Pak $J$ Bot 41(6): 3149-3157.

5. Reddy, YTN, Kurian RM, Kohli RR $\&$ Singh G (2000). Effect of nitrogen, phosphorus and potassium on growth, yield and fruit quality of 'Totapuri' mango (Mangifera indica). Ind $J$ Agric Sci, 70: 475-478.

6. Salisbury, FB \& Ross CW (1992). Mineral nutrition: In Plant Physiology. 4th Ed. Wadsworth Pub. Co. Belmont, California, p. 116-35.

7. Marschner, H (1995). Mineral nutrition of higher plants. Second edition, London Academic Press, p. 889.

8. Pilbeam DJ \& Morely PS (2007). Calcium. In: Barker AV, Pilbeam DJ, editors. Handbook of Plant Nutrition. New York, NY, USA: CRC Press, pp. 121-144.

9. Torres, MD, Farre JM \& Hermoso JM (2004). Nitrogen and calcium fertilization on productivity and fruit quality of mango cv. Sensation. Acta Hort, 645: 394-402.

10. Pinto, ACdeQ, Ramos VHV, Junqueria NTV, Labato E \& Souza DGM (1994). Relacao $\mathrm{Ca} / \mathrm{N}$ nas flohas e seu efeito na producao e qualidade da manga Tommy Atkins sob condicoes de Cerrados. Congresso Bresileiro de Fruticultura, Salvador Bahia, (13): 763.

11. Kertesz, MA, Fellows E \& Schmalenberger A (2007). Rhizobacteria and plant sulfur supply. Adv Appl Microbiol, (62): 235-268.

12. Oostheyse, SA (2000). Variation of leaf nutrition status in relation to fruit growth in mango. Acta Hort, 509: 375-378.

13. Poffley, M \& Owens G (2005). Mango leaf and soil analysis, Agnote No. D41. DPIFM. Northern Territory Government, Australia.

14. Sonneveled, C \& Van Dijk PA (1982). The effectiveness of some washing procedures on the removal of contaminates from plant tissues of glasshouse crops. Commun. Soil Sci Pl Anal 13: 487-496.

15. NFDC 1994. Sulphur status and crop response in Pakistan soils.NFDC publ. No. 2/94, 74 p. National 
Fertilizer Development Center, Islamabad, Pakistan.

16. Williams, $\mathrm{CH} \&$ Steinbergs A (1959). Soil sulphur fractions as chemical indices of available sulphur in some Australian soils. Australian J Agri Res 10: 340-352.

17. Jones, JrJB (1991). Kjeldahl's method for nitrogen determination. MicroMacro Publishing Inc., Athens, GA, USA.

18. Landon, JR (Ed.) (1984). Soil Chemistry. In Booker Tropical Manual, Longman Inc. New York, p. 106-156.

19. NFDC 1994. Sulphur status and crop response in Pakistan soils.NFDC publ. No. 2/94, 74 p. National Fertilizer Development Center, Islamabad, Pakistan.

20. Jackson, ML (1962). Soil chemical analysis. Constable Co. Ltd., London.
21. Ankerman, D \& Richard L (1989). Soil and plant analysis. Agron. Hand Book A and L. Agriculture Laboratories. USA p. 56.

22. Akhtar, MS (1996). Soil mineralogy. In: Soil science. A. Rashid, and K.S. Memon. National Book Foundation, Islamabad, Pakistan. 67-110.

23. Ebeed, S \& Abd El-Majeed MMM (2005). Effect of sparying sucrose and some nutrient elements on Fagri Kalan Mango trees. J App Sci Res, 1(5):341346.

24. Imran, M. \& Gurmani ZA (2011). Role of Macro and Micro nutrients in the plant growth and development. Science Technology and development 30(3): 36-40.

25. Silva, CR (1997). Fruticultura tropical, mangicultura, tecnologiadeproduao. UFLA/ FAEP, Lavra-MG. 